\title{
Effects of umbelliferone in a murine model of allergic airway inflammation
}

\author{
Juliana F. Vasconcelos ${ }^{\mathrm{a}, \mathrm{e}}$, Mauro M. Teixeira ${ }^{\mathrm{b}}$, José M. Barbosa-Filho ${ }^{\mathrm{c}}$, Maria F. Agra ${ }^{\mathrm{c}}$, Xirley P. Nunes ${ }^{\mathrm{d}}$, \\ Ana Maria Giulietti ${ }^{\text {e }}$, Ricardo Ribeiro-dos-Santos ${ }^{\text {a,f }}$, Milena B.P. Soares ${ }^{\text {a,f,* }}$ \\ a Centro de Pesquisas Gonçalo Moniz, Fundação Oswaldo Cruz, 40296-750, Salvador, BA, Brazil \\ b Instituto de Ciências Biomédicas, Universidade Federal de Minas Gerais, 31270-901, Belo Horizonte, MG, Brazil \\ c Laboratório de Tecnologia Farmacêutica, Universidade Federal da Paraíba, 58051-970, João Pessoa, PB, Brazil \\ d Colegiado do Curso de Medicina, Universidade Federal do Vale do São Francisco, 56306-410, Petrolina, PE, Brazil \\ e Departamento de Ciências Biológicas, Universidade Estadual de Feira de Santana, 44031-640, Feira de Santana, BA, Brazil \\ ${ }^{\mathrm{f}}$ Hospital São Rafael. Av. São Rafael, 2152. São Marcos 41253-190, Salvador, BA, Brazil
}

\section{A R T I C L E I N F O}

\section{Article history:}

Received 7 December 2008

Received in revised form 19 February 2009

Accepted 3 March 2009

Available online 14 March 2009

\section{Keywords:}

Umbelliferone

Coumarin

Typha domingensis

Bronquic asthma

(Mouse)

\begin{abstract}
A B S T R A C T
The therapeutic effects of umbelliferone $(30,60$ and $90 \mathrm{mg} / \mathrm{kg}$ ), a coumarin isolated from Typha domingensis (Typhaceae) were investigated in a mouse model of bronchial asthma. BALB/c mice were immunized and challenged by nasal administration of ovalbumin. Treatment with umbelliferone (60 and $90 \mathrm{mg} / \mathrm{kg}$ ) caused a marked reduction of cellularity and eosinophil numbers in bronchoalveolar lavage fluids from asthmatic mice. In addition, a decrease in mucus production and lung inflammation were observed in mice treated with umbelliferone. A reduction of IL-4, IL-5, and IL-13, but not of IFN- $\gamma$, was found in bronchoalveolar lavage fluids of mice treated with umbelliferone, similar to that observed with dexamethasone. The levels of ovalbumin-specific IgE were not significantly altered after treatment with umbelliferone. In conclusion, our results demonstrate that umbelliferone attenuates the alteration characteristics of allergic airway inflammation. The investigation of the mechanisms of action of this molecule may contribute for the development of new drugs for the treatment of asthma.
\end{abstract}

(C) 2009 Elsevier B.V. All rights reserved.

\section{Introduction}

Coumarins constitute a very large class of compounds present in several species belonging to different botanical families, which are widespread in the world. They are secondary metabolites naturally occurring in different parts of the plants, such as roots, flowers and fruits (Leal et al., 2000; Ribeiro and Kaplan, 2002; Razavi et al., 2008). The search for useful pharmaceutical has led to a resurgence of interest in coumarins because these substances display potent and relevant pharmacological activities that are structure-dependent, while at the same time appearing to lack toxicity in mammalian systems (Hoult and Payá, 1996).

Among the biological effects of coumarins are anti-microbian (Thati et al., 2007), anti-viral (Mazzei et al., 2008), anti-thrombotic, vasodilatory (Casley-Smith et al., 1993), antitumoral, antineoplasic, antiinflammatory (Hoult and Payá, 1996; Lino et al., 1997), and antimetastatic properties (Jiménez-Orozco et al., 2001; Finn et al., 2004; Finn et al., 2005; ElinosBáez et al., 2005), and inhibition of acetylcholinesterase and angiotensin converting enzyme (Barbosa-Filho et al., 2006a,b). In humans, coumarins have a short half-life, and its major biotransformation product (75\%) is umbelliferone (Hoult and Payá, 1996; Egan et al., 1997).

Umbelliferone or 7-hydroxycoumarin is a widespread natural product of the coumarin family (Fig. 1). It occurs in many familiar plants from the

\footnotetext{
* Corresponding author. Centro de Pesquisas Gonçalo Moniz, Fundação Oswaldo Cruz, Laboratório de Engenharia Tecidual e Imunofarmacologia. Rua Waldemar Falcão, 121, Candeal. 40296-710, Salvador, Bahia, Brazil. Tel.: + 55713176 2260; fax: + 557131762272.

E-mail address: milena@bahia.fiocruz.br (M.B.P. Soares).
}

Apiaceae (Umbelliferae) family such as carrot, coriander and garden angelica, as well as plants from other families such as the mouse-ear hawkweed. It is a yellowish-white crystalline solid which has a slight solubility in hot water, but high solubility in ethanol (Dean, 1963).

Asthma is a chronic inflammatory disorder of the airways in which many cells and elements play a role, associated with increased airway hyperresponsiveness, leading to recurrent episodes of wheezing, breathlessness, chest tightness, and coughing (Barnes, 2001). This chronic inflammation is characterized by infiltration of eosinophils, neutrophils, mast cells and T cells (Casale et al., 1987; Wenzel, 2003), and is promoted by Th2 type immune responses (Barnes, 2001; El Biaze et al., 2003; Reed, 2006). In the current study we aimed to evaluate the effects of umbelliferone, a coumarin purified from Typha domingensis (Typhaceae), in a mouse model of asthma, as a potential anti-asthmatic agent.

\section{Materials and methods}

\subsection{Plant material}

The aerial parts of $T$. domingensis Pers. were collected for first extracts in March, 2002 in Bravo, State of Bahia, in temporary shallow lake in Dryland "Caatinga" Bioma and after in December, 2005 near the city of Santa Rita, State of Paraíba, Brazil. The plant was identified by Ana Maria Giulietti and Maria de Fátima Agra and the voucher specimens (Giulietti 2035 et al. and Agra 5520 et Góis - JPB) were deposited in the Herbaria HUEFS and JPB. 
<smiles>O=c1ccc2ccc(O)cc2o1</smiles>

Fig. 1. Chemical structure of umbelliferone.

\subsection{Extraction and isolation of umbelliferone}

The aerial parts ( $2000 \mathrm{~g}$ ) of $T$. domingensis were extracted with $95 \%$ ethanol at room temperature. The extract $(150 \mathrm{~g})$ was evaporated under vacuum to yield a brown residue which was suspended in methanol: $\mathrm{H}_{2} \mathrm{O}(3: 7 \mathrm{v} / \mathrm{v})$ and fractionated with chloroform and ethyl acetate. The chloroform phase ( $25 \mathrm{~g}$ ) was subjected to column chromatography over silica gel, eluted with hexane, chloroform and methanol mixtures in an increasing order of polarity, yielding three coumarins and one cinnamic acid derivative. The ethyl acetate phase $(25 \mathrm{~g})$ was subjected to chromatography column over Sephadex LH-20 using methanol yielding two flavonoids. The isolated compounds were identified as coumarin (0.0044\%), scopoletin (0.0014\%) (Brateoeff and Perez-Amador, 1994), umbelliferone $(0.007 \%)$ (Cussans and Huckerby, 1975), p-coumaric acid (0.0016\%), (Pouchert, 1992), quercetin (0.0028\%) (Williams et al., 1971) and isorhamnetin-3-0-glucoside (0.0039\%) (Bilia et al., 1994) based on ${ }^{1} \mathrm{H}$ NMR, ${ }^{13} \mathrm{C}$ NMR, COSY, HMQC and HMBC spectroscopic data and comparison with those reported in the literature.

\subsection{Animals}

Male BALB/c mice, 4-6 weeks old, were used in the experiments. All animals were raised and maintained at the animal facilities of the Gonçalo Moniz Research Center, FIOCRUZ/BA, in rooms with controlled temperature $\left(22 \pm 2{ }^{\circ} \mathrm{C}\right)$ and humidity $(55 \pm 10 \%)$ and continuous air renovation. Animals were housed in a $12 \mathrm{~h}$ light/12 h dark cycle ( 6 am-6 pm) and provided with rodent diet and water ad libitum. Animals were handled according to the NIH guidelines for animal experimentation. All procedures described here had prior approval from the local animal ethics committee.

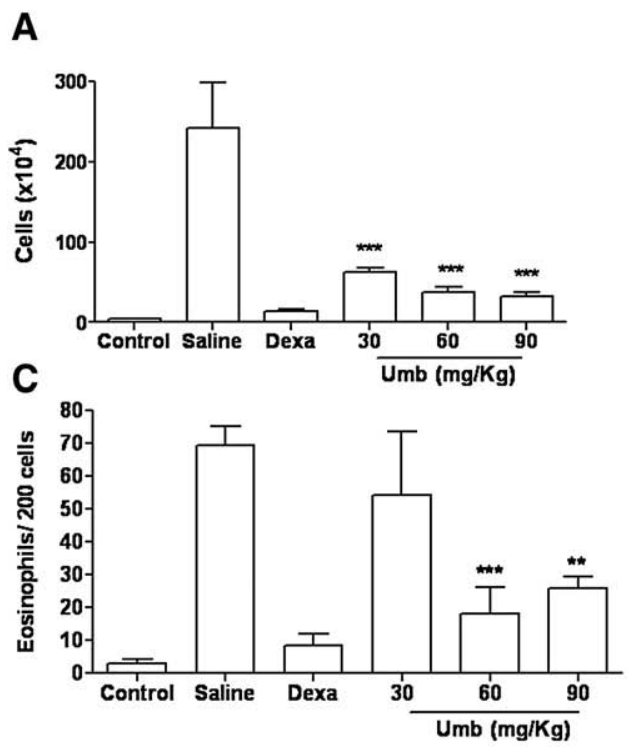

\subsection{Sensitization and challenge with ovalbumin and treatment}

Allergic airway inflammation was induced as described before (Vasconcelos et al., 2008). Groups of seven mice received systemic immunization by subcutaneous injection of $10 \mu \mathrm{g}$ of chicken egg ovalbumin (Grade V, $>98 \%$ pure; Sigma, St Louis, MO) diluted in $2 \mathrm{mg} / \mathrm{ml}$ alum (AlumImject; Pierce, Rockford, IL) followed by a booster injection at day 14 . A nasal challenge was performed starting at day 28 , by inhalational exposure to aerosolised ovalbumin for $15 \mathrm{~min} /$ day, on five consecutive days. Exposures were carried out in an acrylic box. A solution of $1 \%$ ovalbumin in saline was aerosolised by delivery of compressed air to a sidestream jet nebuliser (RespiraMax, NS, Brazil). Two hours before each aerosol delivery, mice were treated orally with umbelliferone (30,60, and $90 \mathrm{mg} / \mathrm{kg}$ ), dexamethasone $(30 \mathrm{mg} / \mathrm{kg}$ ) or vehicle (10\% DMSO in saline).

\subsection{Collection of blood and bronchoalveolar lavage}

Twenty four hours after the last inhalational exposure, mice were anesthetized and bled via the brachial plexus for collection of blood samples used to estimate the IgE production. Bronchoalveolar lavage (BAL) was performed twice by intratracheal instillation of $1 \mathrm{ml}$ of PBS. The first lavage fluid was centrifuged, and aliquots of the supernatant were kept at $70{ }^{\circ} \mathrm{C}$ until use for cytokine measurements. The second lavage fluid was centrifuged and the two cell pellets were resuspended in a PBS final volume of $1 \mathrm{ml}$. The number of total leukocytes in bronchoalveolar lavage fluid was estimated in a Neubauer chamber. Differential counts were obtained using panotic-stained cytospin preparations. A differential count of 200 cells was made in a blinded fashion and according to standard morphologic criteria.

\subsection{Histopathological and morphometric analysis}

The right lobe of the lungs from each animal was removed for histological analysis. The lung was inflated via the tracheal cannula with $4 \%$ buffered formalin, fixed in the same solution, and embedded in paraffin. Sections were stained with hematoxylin and eosin for quantification of inflammatory cells by optical microscopy. For each lung 10 fields $(400 \times)$ were analyzed per section, and the data used to calculate the mean number of cells per $\mathrm{mm}^{2}$. Mucus production was

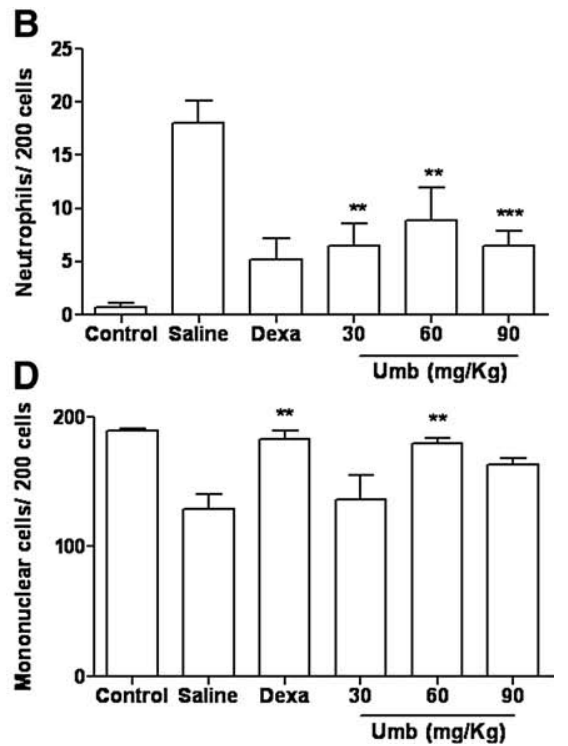

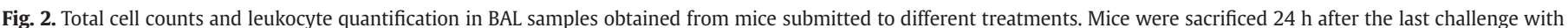

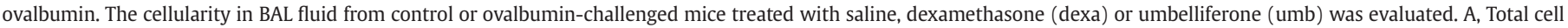

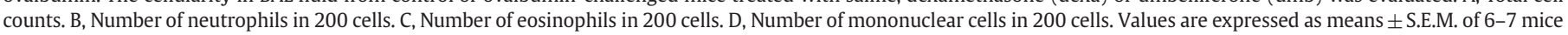
per group, in one of two experiments performed. ${ }^{* * *} P<0.001$. 
analyzed in alcian blue-stained sections. All images were digitalized using a color digital video camera (CoolSnap cf) adapted to a BX41 microscope (Olympus, Tokyo, Japan) calibrated with a reference measurement slide and were analyzed using Image Pro image program (version 6.1; Media Cybernetics, San Diego, CA, USA).

\subsection{Ovalbumin-specific IgE antibody levels and cytokine production}

IgE antibody levels to ovalbumin in sera samples from individual animals were quantified using an enzyme immunoassay modified from Jungsuwadee et al. (2004). Briefly, microplate wells coated with $2 \mu \mathrm{g} / \mathrm{ml}$ of anti-mouse IgE (Pharmingem, San Diego, CA) were incubated overnight with dilutions of the test samples in PBS containing 5\% nonfat milk. Detection of bound anti-ovalbumin IgE was performed by sequential ovalbumin incubation followed by biotinylated anti-ovalbumin antibody (Fitzgerald, Concord, MA, USA). After incubation with streptoavidin-peroxidase conjugate, the reaction was developed using 3,3',5,5'-tetramethylbenzidine (TMB) peroxidase substrate and read at $450 \mathrm{~nm}$. Concentrations of interleukin (IL)-4, IL-5, IL-13, and interferon
(IFN)- $\gamma$ in bronchoalveolar lavage fluid were also determined by ELISA using specific antibody kits (R\&D System, Minnesota, MN, USA), according to manufacturer's instructions.

\subsection{Statistical analysis}

Results were expressed as means \pm S.E.M. of 7 mice per group. Statistical comparisons between groups were performed by analysis of variance (ANOVA) followed by Newman-Keuls multiple comparison test, using GraphPad InStat program (Software Inc., San Diego, CA, USA). Results were considered to be statistically significant when $P<0.05$.

\section{Results}

\subsection{Treatment with umbelliferone reduces lung inflammation}

Mice sensitized and challenged with ovalbumin have increased the number of inflammatory cells in bronchoalveolar lavage fluid, compared to control mice - sensitized and challenged with saline (Fig. 2A). The

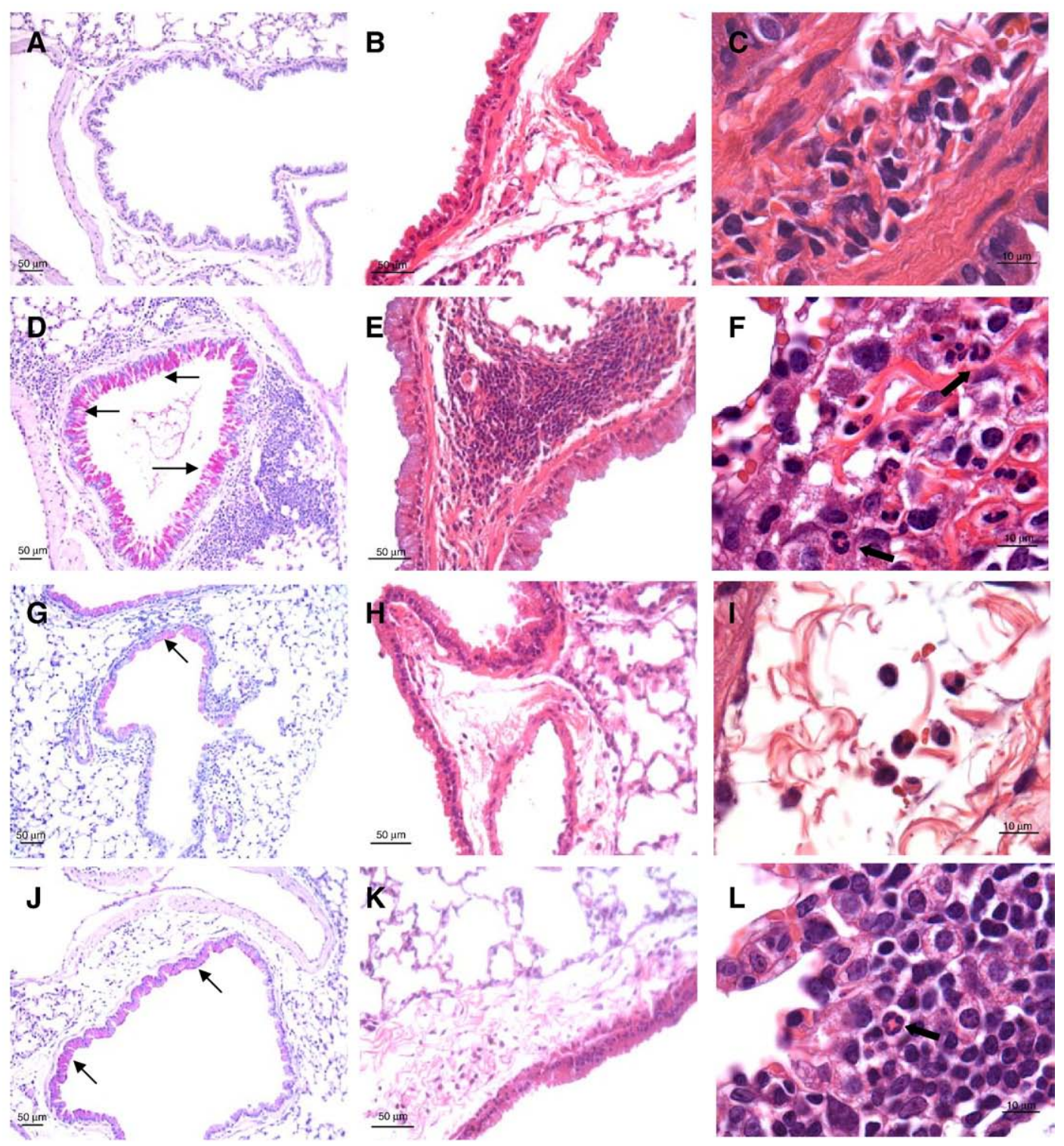

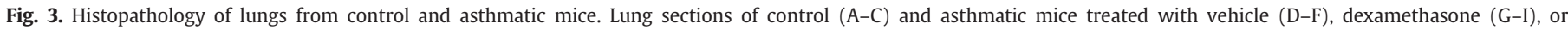

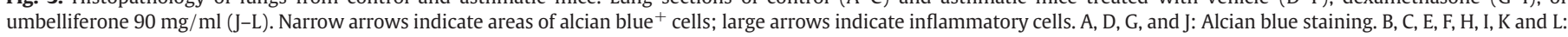
H\&E staining. 



Fig. 4. Quantification of inflammation and mucus production in lungs of mice. A, Intensity of inflammation in lungs of mice treated with saline, dexamethasone (dexa) or umbelliferone $60 \mathrm{mg} / \mathrm{ml}$ (umb) compared to control animals. The number of inflammatory cells was evaluated on H\&E-stained sections. B, Analysis of mucus production on alcian blue-stained lung sections. The area of alcian blue staining was estimated by morphometric analysis. Data are expressed as means \pm S.E.M. of 7 mice per group, in one of two experiments performed. ${ }^{* * *} P<0.001$ compared to saline-treated mice.

effects of umbelliferone treatment in lung inflammation were evaluated comparing bronchoalveolar lavage fluid cytology of umbelliferonetreated mice to that of mice treated with vehicle. The number of total cells and of neutrophils in the bronchoalveolar lavage fluid was significantly reduced after umbelliferone treatment compared to vehicle-treated mice (Fig. 2A and B). A significant inhibition was observed in mice treated with dexamethasone, a gold standard drug. Treatment with umbelliferone at 60 and $90 \mathrm{mg} / \mathrm{ml}$, but not at $30 \mathrm{mg} / \mathrm{ml}$, decreased significantly the number of eosinophils found in the bronchoalveolar lavage fluid of challenged mice, although dexamethasone caused a more



Fig. 6. Ovalbumin-specific IgE antibodies in asthmatic mice. The levels of anti-OVA IgE antibodies were determined in the sera of individual mice by ELISA. The data are expressed as means \pm S.E.M. of 7 mice per group, in one of two experiments performed. $* * P<0.01$ compared to saline-treated mice.

potent reduction in the number of eosinophils (Fig. 2C). The number of mononuclear cells was significantly altered only by treatment with umbeliferone at $60 \mathrm{mg} / \mathrm{ml}$ and by dexamethasone (Fig. 2D).

\subsection{Histological evaluation of lungs from umbelliferone-treated mice}

To characterize further the changes in lung pathology caused by antigen challenge of immunized mice, we examined lung sections stained with H\&E. Ovalbumin challenge caused an intense cell infiltrate containing many lymphocytes, macrophages, and eosinophils (Fig. 3E and F). Mice treated with umbelliferone at 60 and $90 \mathrm{mg} / \mathrm{ml}$, but not at $30 \mathrm{mg} / \mathrm{ml}$, had reduced inflammation, particularly reduced eosinophil infiltration, although some less dense inflammatory foci remained (Fig. 3K and L; Fig. 4A). Dexamethasone treatment almost completely eliminated the inflammatory infiltrate, in particular eosinophils (Fig. 3H and I; Fig. 4A).

Lung sections were stained with alcian blue to analyze mucus overproduction. Lungs from control mice revealed rare alcian blue ${ }^{+}$ cells in the respiratory epithelium compared to saline-treated group, which had high alcian blue ${ }^{+}$staining (Fig. 3 A and D; Fig. 4B). Similar to dexamethasone, umbelliferone treatment at $60 \mathrm{mg} / \mathrm{ml}$ was capable of modulating mucus production, decreasing the intensity of alcian blue ${ }^{+}$staining observed in the saline-treated group by $38 \%$
A

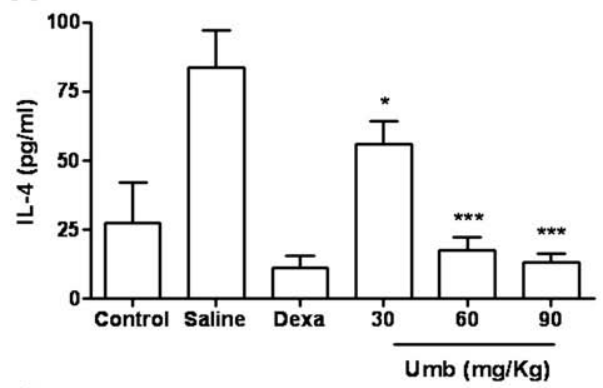

C

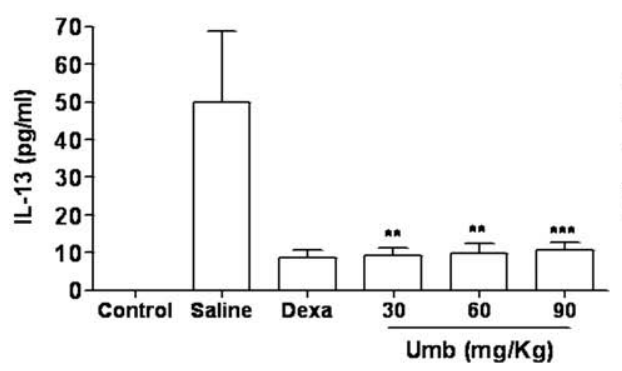

B

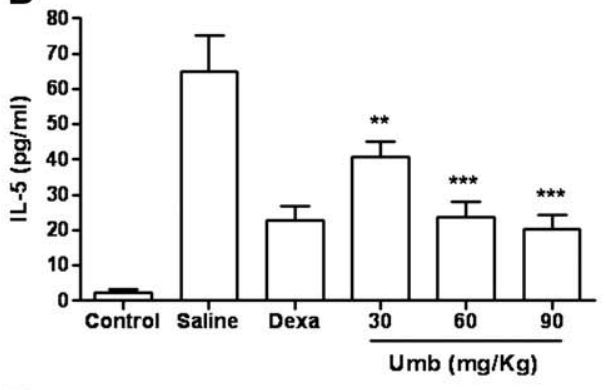

D

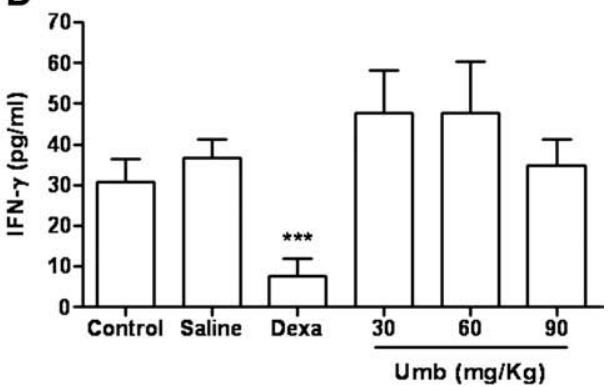

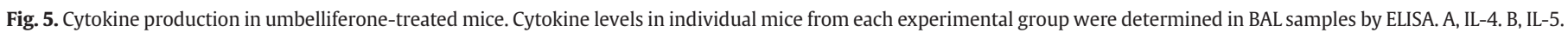
C, IL-13. D, IFN- $\gamma$. Data are expressed as means \pm S.E.M. of 6-7 mice per group. ${ }^{* *} P<B 0.01 ; * * * P<0.001$ compared to saline-treated mice. 
and a more potent effect after umbelliferone treatment at $90 \mathrm{mg} / \mathrm{ml}$ (Fig. 3G and J; Fig. 4B).

\subsection{Treatment with umbelliferone modulated T-helper type 2 cytokine response but not IgE production}

The production of cytokines was studied in bronchoalveolar lavage of individual mice from each group. As expected, the concentrations of IL-4, IL-5, and IL-13 were increased in ovalbumin-immunized, compared to control mice (Fig. 5A-C). Treatment with umbelliferone caused a reduction in the levels of Th2-associated cytokines, compared to salinetreated group, an effect similar to that of dexamethasone. The levels of Th1-associated cytokine IFN- $\gamma$ were not increased by ovalbumin challenge, but were reduced by dexamethasone. In contrast, umbelliferone did not alter the production of IFN- $\gamma$ (Fig. 5D).

When levels of ovalbumin-specific IgE antibodies were analyzed, ova-immunized mice treated with vehicle had high levels of serum anti-ovalbumin IgE antibodies compared to control mice (Fig. 6). A significant reduction in ovalbumin-specific IgE antibodies was observed in mice treated with dexamethasone, but not with umbelliferone, compared to saline-treated controls (Fig. 6).

\section{Discussion}

In the present study we demonstrated a potent anti-inflammatory activity of umbelliferone in an allergic airway inflammation model induced by ovalbumin administration in mice. This effect was evidenced by a marked reduction of inflammation both in bronchoalveolar lavage fluid and in the lung, especially in neutrophil and eosinophil numbers, in mucus production and in the levels of Th2-associated cytokines in bronchoalveolar lavage after umbelliferone treatment.

Umbelliferone is one of several coumarins with anti-inflammatory activity already reported (Hoult and Payá 1996; Lino et al., 1997). In our study it was extracted from $T$. domingensis (Typhaceae), a species widely distributed in north-east Brazil, especially found in damp areas and in shallow water, lakes and river margins, used for water and soil metal decontamination (Taggart et al., 2005; França, 2006; Maine et al., 2007). We have isolated three coumarins from $T$. dominguensis. The most abundant was identified as coumarin or 1,2-benzopyrone with effects already described in an experimental asthma model (Marinho et al., 2004; Biavatti et al., 2004; Zhang et al., 2005; Dos Santos et al., 2006; Werz, 2007). The other two were scopoletin, isolated in small amounts, and umbelliferone, which has not been studied in animal models of asthma before.

Umbelliferone is present in Typhae Pollen, a traditional Chinese herbal medicine with demonstrated immunomodulatory activity (Park et al., 2004; Qin \& Sun, 2005). Thus, umbelliferone may be one of the substances responsible for the anti-inflammatory effects of this extract. A recent study of some plant species largely used in north-eastern Brazil for respiratory tract diseases has shown they have in common coumarins as one of their active principles (Leal et al., 2000; Agra et al., 2007). Ramanitrahasimbola et al. (2005) showed that the bronchodilator effect after treatment with Phymatodes scolopendria extract, a plant used to treat respiratory disorders, is mainly caused by coumarins. Our results support the protective role of coumarins in asthma.

Studies on the pharmacokinetics of coumarin in man have shown there is extensive first-pass metabolism after oral administration (Ritschel et al., 1979; Ritschel and Hoffmann, 1981; Ritschel, 1984). This, and other pharmacokinetic data in man, has led to suggestions that coumarin is a prodrug, most likely active as umbelliferone or, possibly, even as the 7-hydroxyglucuronide form after metabolization in the liver (Hoult and Payá, 1996). Baccard et al. (2000) also suggested that umbelliferone was vasodilating activity. Our results demonstrate that the effects of umbelliferone go beyond a bronchodilating effect, since it has also potent immunomodulatory effects, downregulating cytokine and mucus production and inflammation.
The effects of umbelliferone in the reduction of histological alterations and cellularity in the bronchoalveolar lavage fluid were similar to those of dexamethasone, a synthetic glucocorticoid commonly used as a gold standard anti-inflammatory drug. The side effects after chronic use of corticoids, such as osteopenia, poor wound healing, hyperglycemia, hypertension, and cataracts limit their systemic administration (Barnes, 2001; Schimmer \& Parker, 2001), and therefore the search of substances with similar immunosuppressive activities, free or with lower toxicity, is of great interest (Marinho et al., 2004; Bezerra-Santos et al., 2006; Costa et al., 2008a,b).

Although reports of adverse effects in humans resulting from coumarin administration are rare (Casley-Smith et al., 1993; Lake, 1999), it is acutely toxic to laboratory animals in chronic oral gavage administration at doses equal or higher of $200 \mathrm{mg} / \mathrm{kg}$ (Born et al., 2003). There are marked differences in coumarin metabolism between susceptible rodent and other species, including humans. According to Lake (1999) the 7-hydroxylation pathway of coumarin metabolism, which generates umbelliferone, is usually the major pathway in humans but not in rats and mice, in which it represents only a minor pathway of metabolism. In contrast, the major route of coumarin metabolism in murines is by a 3,4-epoxidation pathway, which results in the formation of toxic metabolites. In our study we did not observe any signs of toxicity in umbelliferone-treated mice.

Carrageenan stimulates the release of several inflammatory mediators such as histamine, serotonin, bradykinin and prostaglandins. Nonsteroidal anti-inflammatory drugs (NSAID) block the synthesis of prostaglandins by inhibiting cyclooxygenase (COX) (Hoult et al., 1994). Murakami et al. (2000) demonstrated umbelliferone does not suppress $\mathrm{O}_{2}^{-}$generation in vitro nor attenuates lypopolysaccharide-induced nitric oxide synthase (NOS)/COX-2 expression and TNF- $\alpha$ release. Interesting, umbelliferone inhibits prostaglandin biosynthesis, which involves fatty acid hydroperoxy intermediates, indicating that this substance has a mechanism of action similar to NSAID in a carrageenan-induced inflammation model (Fylaktakidou et al., 2004). This is an unlikely mechanism of action of umbelliferone in our system, NSAID are not shown to inhibit effectively the migration of eosinophils and mucus production in murine models of allergic inflammation.

There are certain pharmacologic compounds that inhibit eosinophil function, eosinophil infiltration, or both, which is desirable for the treatment of patients with atopy/ allergic disorders (Barnes, 2001). The inhibition of Type-II cytokine production by umbelliferone suggests an inhibition of $\mathrm{T}$ cells and may be underlining the effects of the drug on the system, as allergic airway inflammation is shown to depend on the action of IL-4, IL-5 and IL-13 (Bodey et al., 1999; Boyton and Altmann, 2004). It has also been shown that IL-5 enables terminal differentiation and proliferation of eosinophil precursors, as well as the eosinophil activation effect (Barnes, 2001). The reduction of eosinophil infiltrates found in umbelliferone-treated asthmatic mice may be due to IL- 5 reduction, since it promotes the differentiation to and activation of eosinophils. Further studies are clearly needed to understand further the ability of umbelliferone to inhibit the synthesis of these cytokines.

Ovalbumin-specific IgE production was not significantly altered after treatment with umbelliferone, suggesting that this compound did not affect the production of IgE by activated B cells, in contrast to dexamethasone, which caused a decrease on the levels of IgE. This effect of dexamethasone on IgE levels in the mouse model of allergic airway inflammation has been demonstrated before (Zhao et al., 2007).

In allergic asthma, the inhibition of macrophages, $\mathrm{T}$ lymphocytes, eosinophils, mast cells, and mucus secretion leads to an improvement of respiratory flow. Altogether, our results show that umbelliferone attenuates airway inflammation in a murine model of asthma. The effects described herein, as well as those observed by other investigators, together with the broad spectrum of the biological effects of this substance, strongly suggest the therapeutic potential of umbelliferone for the treatment of asthma and other allergic diseases. 


\section{Acknowledgements}

This work had the financial support of FIOCRUZ, CNPq, Institutos do Milênio, IMSEAR, MCT, FINEP, RENORBIO, and CAPES. The authors wish to thank Ricardo Santana de Lima and Daniele Brustolim for their technical assistance.

\section{References}

Agra, M.F., França, P.F., Barbosa-Filho, J.M., 2007. Synopsis of the plants known as medicinal and poisonous in Northeast of Brazil. Braz. J. Pharmacogn. 17, 114-140.

Baccard, N., Mechiche, H., Nazeyrollas, P., Manot, L., Lamiable, D., Devillier, P., Millart, H., 2000. Effects of 7-hydroxycoumarin (umbelliferone) on isolated perfused and ischemic-reperfused rat heart. Arzneimittel-Forsch. 50, 890-896.

Barbosa-Filho, J.M., Medeiros, K.C.P., Diniz, M.F.F.M., Batista, L.M., Athayde-Filho, P.F, Silva, M.S., Cunha, E.V.L., Almeida, J.R.G.S., Quintans-Júnior, L.J., 2006a. Natura products inhibitors of the enzyme acetylcholinesterase. Braz. J. Pharmacogn. 16, $258-285$

Barbosa-Filho, J.M., Martins, V.K.M., Rabelo, L.A., Moura, M.D., Silva, M.S., Cunha, E.V.L., Souza, M.F.V., Almeida, R.N., Medeiros, I.A., 2006b. Natural products inhibitors of the angiotensin converting enzyme (ACE). A review between 1980-2000. Braz. J. Pharmacogn. 16, 421-446.

Barnes, P.J., 2001. Corticosteroids, IgE, and atopy. J. Clin. Invest. 107, 265-266.

Bezerra-Santos, C.R., Vieira-de-Abreu, A., Barbosa-Filho, J.M., Bandeira-Melo, C. Piuvezam, M.R., Bozza, P.T. 2006. Anti-allergic properties of Cissampelos sympodialis and its isolated alkaloid warifteine. Int. Immunopharmacol. 6, 1152-1160.

Biavatti, M.W., Koerich, C.A., Henck, C.H., Zucatelli, E., Martineli, F.H., Bresolin, T.B., Leite, S.N., 2004. Coumarin content and physicochemical profile of Mikania laevigata extracts. Z. Nat. forsch. C J. Biosci. 59, 197-200.

Bilia, A.R., Muñoz-Gonzalez, J., Morelli, I., Nieri, E., Escudero-Rubio, M., 1994. Flavono glycosides from Pyrus bourgaeana. Phytochemistry 35, 1378-1380.

Bodey, K.J., Semper, A.E., Redington, A.E., Madden, J., Teran, L.M., Holgate, S.T., Frew, A.J., 1999. Cytokine profiles of BAL T cells and T-cell clones obtained from human asthmatic airways after local allergen challenge. Allergy 54, 1083-1093.

Boyton, R.J., Altmann, D.M., 2004. Asthma: new developments in cytokine regulation. Clin. Exp. Immunol. 136, 13-14.

Brateoeff, E.A., Perez-Amador, M.C., 1994. Phytochemical study of Typha domingensis Pers. (Typhaceae). Phyton (B. Aires) 55, 71-74

Born, S.L., Api, A.M., Ford, R.A., Lefever, F.R., Hawkins, D.R., 2003. Comparative metabolism and kinetics of coumarin in mice and rats. Food Chem. Toxicol. 41, 247-258.

Casale, T.B., Wood, D., Richerson, H.B., Zehr, B., Zavala, D., Hunninghake, G.W., 1987 Direct evidence of a role for mast cells in the pathogenesis of antigen-induced bronchoconstriction. J. Clin. Invest. 80, 1507-1511.

Casley-Smith, R., Wang, C.T., Casley-Smith, J.R., Zi-hai, C., 1993. Treatment of filarial lymphoedema and elephantiasis with 5,6-benzo-alpha-pyrone (coumarins). BM 307, 1037-1041.

Costa, H.F., Bezerra-Santos, C.R., Barbosa-Filho, J.M., Piuvezam, M.R., 2008a. Warifteine, a bisbenzylisoquinoline alkaloid, decreases immediate allergic and therma hyperalgesic reactions in sensitized animals. Int. Immunopharmacol. 8, 519-525.

Costa, J.F.O., David, J.P.L., David, J.M., Giulietti, A.M., Queiroz, L.P., Santos, R.R., Soares, M.B. 2008b. Immunomodulatory activity of extracts from Cordia superberba Cham. and Cordia rufescens A. DC. (Boraginaceae), plant species native from Brazilian Semi-arid. Braz. J. Pharmacogn. 18, 11-15.

Cussans, N.J., Huckerby, T.N., 1975. C-13 NMR-spectroscopy of heterocyclic-compounds. IV. MHz study of chemical-shifts and carbon-proton coupling-constants in a series of hydroxy, methoxy and glucosyl coumarins. Tetrahedron 31, 2719-2726.

Dean, F.M., 1963. Naturally Occurring Oxygen Ring Compounds. Butterworths, London.

Dos Santos, S.C., Krueger, C.L., Steil, A.A., Kreuger, M.R., Biavatti, M.W., Wisniewski Jr., A 2006. LC characterisation of guaco medicinal extracts, Mikania laevigata and $M$. glomerata, and their effects on allergic pneumonitis. Planta Med. 72, 679-684.

Egan, D., James, P., Cooke, D., O'Kennedy, R., 1997. Studies on the cytostatic and cytotoxic effects and mode of action of 8-nitro-7-hydroxycoumarin. Cancer Lett. 118, 201-211.

El Biaze, M., Boniface, S., Koscher, V., Mamessier, E., Dupuy, P., Milhe, F., Ramadour, M. Vervloet, D., Magnan, A., 2003. T cell activation, from atopy to asthma: more a paradox than a paradigm. Allergy 58, 844-853.

Elinos-Báez, C.M., León, F., Santos, E., 2005. Effects of coumarin and 7OH-coumarin on bcl-2 and Bax expression in two human lung cancer cell lines in vitro. Cell. Biol. Int 29, 703-708.

França, F., 2006. Typhaceae, In: Giulietti, A.M., Conceição, A., Queiroz, L.P. (Eds.), Instituto do Milênio do Semi-árido: Diversidade e caracterização das Fanerógamas do semi-árido brasileiro, 1st ed. Recife, APNE/MCT

Finn, G.J., Creaven, B.S., Egan, D.A., 2004. Investigation of intracellular signalling events mediating the mechanism of action of 7-hydroxycoumarin and 6nitro-7-hdroxycoumarin in human renal cells. Cancer Lett. 205, 69-79.

Finn, G.J., Creaven, B.S., Egan, D.A., 2005. Activation of mitogen activated protein kinase pathways and melanogenesis by novel nitro-derivatives of 7-hydroxycomarin in human malignant melanoma cells. Eur. J. Pharm. Sci. 26, 16-25.

Fylaktakidou, K.C., Hadjipavlou-Litina, D.J., Litinas, K.E., Nicolaides, D.N., 2004. Natural and synthetic coumarin derivatives with anti-inflammatory/antioxidant activities. Curr. Pharm. Des. 10, 3813-3833.
Hoult, J.R., Forder, R.A., de las Heras, B., Lobo, I.B., Payá, M., 1994. Inhibitory activity of a series of coumarins on leukocyte eicosanoid generation. Agents Actions 1, 44-49.

Hoult, J.R.S., Payá, M., 1996. Pharmacological and biochemical actions of simple coumarins: natural products with therapeutic potential. Gen. Pharmacol. 27, 713-722.

Jiménez-Orozco, F.A., López-González, J.S., Nieto-Rodriguez, A., Velasco-Velázquez, M.A., Molina-Guarneros, J.A., Mendoza-Patiño, N., García-Mondragón, M.J., Elizalde-Galvan, P., León-Cedeño, F., Mandoki, J.J., 2001. Decrease of cyclin D1 in the human lung adenocarcinoma cell line A-427 by 7-hydroxycoumarin. Lung Cancer 34, 185-194.

Jungsuwadee, P., Dekan, G., Stingl, G., Epstein, M.M., 2004. Inhaled dexamethasone differentially attenuates disease relapse and established allergic asthma in mice. Clin. Immunol. 110, 13-21.

Lake, B.G., 1999. Coumarin metabolism, toxicity and carcinogenicity: relevance for human risk assessment. Food Chem. Toxicol. 37, 423-453.

Leal, L.K.A.M., Ferreira, A.A.G., Bezerra, G.A., Matos, F.J.A., Viana, G.S.B., 2000. Antinociceptive, anti-inflammatory and bronchodilator activities of Brazilian medicinal plants containing coumarin: a comparative study. J. Ethnopharmacol. 70, 151-159.

Lino, C.S., Taveira, M.L., Viana, G.S.B., Matos, F.J.A., 1997. Analgesic and antiinflammatory activities of Justicia pectoralis Jacq and its main constituents: coumarin and umbelliferone. Phytother. Res. 11, 211-215.

Maine, M.A., Suñe, N., Hadad, H., Sánchez, G., Bonetto, C., 2007. Influence of vegetation on the removal of heavy metals and nutrients in a constructed wetland. J. Environ. Manag. 90, 355-363.

Marinho, M.G.V., Brito, A.G., Carvalho, K.A., Bezerra-Santos, C.R., Andrade, L.H.C., Barbosa-Filho, J.M., Piuvezam, M.R., 2004. Amburana cearensis e cumarina imunomodulam os níveis de anticorpos antígeno-específico em camundongos BALB/c sensibilizados com ovalbumina. Acta. Farm. Bonaer. 23, 47-52.

Mazzei, M., Nieddu, E., Miele, M., Balbi, A., Ferrone, M., Fermeglia, M., Mazzei, M.T., Pricl, S., La Colla, P., Marongiu, F., Ibba, C., Loddo, R., 2008. Activity of Mannich bases of 7hydroxycoumarin against Flaviviridae. Bioorg. Med. Chem. 16, 2591-2605.

Murakami, A., Nakamura, Y., Tanaka, T., Kawabata, K., Takahashi, D., Koshimizu, K., Ohigashi, H., 2000. Suppression by citrus auraptene of phorbol ester- and endotoxin-induced inflammatory responses: role of attenuation of leukocyte activation. Carcinogenesis 21, 1843-1850.

Park, W.H., Park, S.Y., Kim, H.M., Kim, C.H., 2004. Effect of a Korean traditional formulation, Hwaotang, on superoxide generation in human neutrophils, platelet aggregation in human blood, and nitric oxide, prostaglandin E2 production and paw oedema induced by carrageenan in mice. Immunopharmacol. Immunotoxicol. $26,53-73$.

Pouchert, C.J., 1992. Aldrich Library of $13 \mathrm{C}$ and $1 \mathrm{H}$ FT NMR Spectra. Aldrich Chemical Co, USA.

Qin, F., Sun, H., 2005. Immunosuppressive activity of pollen typhae ethanol extract on the immune responses in mice. J. Ethnopharmacol. 102, 424-429.

Ramanitrahasimbola, D., Rakotondramanana, D.A., Rasoanaivo, P., Randriantsoa, A., Ratsimamanga, S., Palazzino, G. Galeffi, C. Nicoletti, M., 2005. Bronchodilator activity of Phymatodes scolopendria (Burm.) Ching and its bioactive constituent. J. Ethnopharmacol. 102, 400-407.

Razavi, S.M., Nazemiyeh, H., Hajiboland, R., Kumarasamy, Y., Delazar, A., Nahar, L., Sarker, S.D., 2008. Coumarins from the aerial parts of Prangos uloptera (Apiaceae). Braz. J. Pharmacogn. 18, 1-5

Reed, C.E., 2006. The natural history of asthma. J. Allergy Clin. Immunol. 118, 543-548.

Ribeiro, C.V.C., Kaplan, M.A.C., 2002. Tendências evolutivas de famílias produtoras de cumarinas em angiospermae. Quim. Nova 25, 533-538.

Ritschel, W.A., Brady, M.E., Tan, H.S.I., 1979. First-pass effect of coumarin in man. Int. J. Clin. Pharmacol. Biopharm. 17, 99-103.

Ritschel, W.A., Hoffmann, K.A., 1981. Pilot study on bioavailability of coumarin and 7hydroxycoumarin upon peroral administration of coumarin in a sustained-release dosage form. J Clin. Pharmacol. 21, 294-300.

Ritschel, W.A., 1984. Therapeutic concentration of coumarin and predicted dosage regimens. Arzneim. Forsch. (Drug Res) 34, 907-909.

Schimmer, B.P., Parker, K.L., 2001. Adrenocorticotropic hormone; adrenocortical steroids and their synthetic analogs; inhibitors of the synthesis and actions of adrenocortical hormones, In: Hardman, J.G. Limbird, L.E., Goodman, Gilman A. (Eds.), The Pharmacological Basis of Therapeutics, 10th ed. McGraw-Hill, New York7.

Taggart, M.A., Carlisle, M., Pain, D.J., Williams, R., Green, D., Osborn, D., Meharg, A.A., 2005. Arsenic levels in the soils and macrophytes of the 'Entremuros' after the Aznalcóllar mine spill. Environ. Pollut. 133, 129-138.

Thati, B., Noble, A., Rowan, R., Creaven, B.S., Walsh, M., McCann, M., Egan, D., Kavanagh, K., 2007. Mechanism of action of coumarin and silver (I)-coumarin complexes against the pathogenic yeast Candida albicans. Toxicol. in Vitro 21, 801-808.

Vasconcelos, J.F., Teixeira, M.M., Barbosa-Filho, J.M., Lúcio, A.S.S.C., Almeida, J.R.G.S., de Queiroz, L.P., Ribeiro-dos-Santos, R., 2008. The triterpenoid lupeol attenuates allergic airway inflammation in a murine model. Int. Immunopharmacol. 8, 1216-1221.

Wenzel, S., 2003. Mechanisms of severe asthma. Clin. Exp. Allergy 33, 1622-1628.

Werz, O., 2007. Inhibition of 5-lipoxygenase product synthesis by natural compounds of plant origin. Planta Med. 73, 1331-1357.

Williams, C.A., Harborne, J.B., Clifford, H.T., 1971. Comparative biochemistry of flavonoids. XIV. Flavonoid patterns in monocotyledons - flavonols and flavones in some families associated with Poaceae. Phytochemistry 10, 1059.

Zhang, S.-Y., Meng, L., Gao, W.-Y., Song, N.-N., Jia, W., Duan, H.-Q., 2005. Advances on biological activities of coumarins. Zhongguo Zhongyao Zazhi 30, 410-414.

Zhao, J., Yeong, L.H., Wong, W.S., 2007. Dexamethasone alters bronchoalveolar lavage fluid proteome in a mouse asthma model. Int Arch. Allergy Immunol. 142, 219-229. 